\title{
An evaluation model for landslide and debris flow prediction using multiple hydrometeorological variables
}

\author{
Jinjin $\mathrm{Hou}^{1}$, Ming Dou ${ }^{1}$, yong Zhang ${ }^{2}$, Jihua Wang ${ }^{3}$, and Guiqiu $\mathrm{Li}^{1}$ \\ ${ }^{1}$ Zhengzhou University \\ ${ }^{2}$ Chinese Academy of Sciences \\ ${ }^{3}$ Geological Environmental Monitoring Institute of Henan Province
}

June 23, 2020

\begin{abstract}
Landslide and debris flows are typically triggered by rainfall-related weather conditions, including short-duration storms and long-lasting rainfall. The critical precipitation of landslide and debris flow occurrence is different under various hydrometeorological conditions. In this study, the daily hydrological states were evaluated by the SWAT model, and the trigger sensitivities of different daily hydrological variables were assessed with 50 days recorded landslide and debris flows between 2010 and 2013. Based on modeled wetness states, the event days were divided into LLR-trigger event days (long-lasting rainfall) and SDStrigger event days (short-duration storm) with six determinate criteria. The landslide and debris flow prediction model was built using nine hydrometeorological variables and the predictive performance was tested with simulated data from 2010 to 2012. The results suggest that: Historical hydrological variables and their development provide important information for triggering debris flows, though rainfall is the most important factor for triggering debris flows. The landslides and debris flows in the selected subbasins region are triggered on 33 days by LLR and on 17 days by SDS. Specifically, LLR type landslide and debris flow account for a large proportion in July, while SDS type landslide and debris flow occur more frequently in September. The prediction model with the AUC value of 0.85 , can capture most of the landslide debris flow. The temporal distribution of the two triggering-event predicted by the model is consistent with the annual distribution of precipitation. Besides, there are spatial variations of the specific trigger types in the different subbasins, which attribute to the different land cover. Despite some uncertainty, this study thereby provides an idea of improving the landslide and debris flow prediction model.
\end{abstract}

\section{Hosted file}

Manuscript.pdf available at https://authorea.com/users/336123/articles/461900-an-evaluationmodel-for-landslide-and-debris-flow-prediction-using-multiple-hydrometeorologicalvariables

\section{Hosted file}

Figugre_1.docx available at https://authorea.com/users/336123/articles/461900-an-evaluationmodel-for-landslide-and-debris-flow-prediction-using-multiple-hydrometeorologicalvariables

\section{Hosted file}

Figugre_2.docx available at https://authorea.com/users/336123/articles/461900-an-evaluationmodel-for-landslide-and-debris-flow-prediction-using-multiple-hydrometeorologicalvariables

\section{Hosted file}


Figugre_3.docx available at https://authorea.com/users/336123/articles/461900-an-evaluationmodel-for-landslide-and-debris-flow-prediction-using-multiple-hydrometeorologicalvariables

\section{Hosted file}

Figugre_4.docx available at https://authorea.com/users/336123/articles/461900-an-evaluationmodel-for-landslide-and-debris-flow-prediction-using-multiple-hydrometeorologicalvariables

\section{Hosted file}

Figugre_5.docx available at https://authorea.com/users/336123/articles/461900-an-evaluationmodel-for-landslide-and-debris-flow-prediction-using-multiple-hydrometeorologicalvariables

\section{Hosted file}

Figugre_6.docx available at https://authorea.com/users/336123/articles/461900-an-evaluationmodel-for-landslide-and-debris-flow-prediction-using-multiple-hydrometeorologicalvariables

\section{Hosted file}

Figugre_7.docx available at https://authorea.com/users/336123/articles/461900-an-evaluationmodel-for-landslide-and-debris-flow-prediction-using-multiple-hydrometeorologicalvariables

\section{Hosted file}

Figugre_8.docx available at https://authorea.com/users/336123/articles/461900-an-evaluationmodel-for-landslide-and-debris-flow-prediction-using-multiple-hydrometeorologicalvariables

\section{Hosted file}

Figugre_9.docx available at https://authorea.com/users/336123/articles/461900-an-evaluationmodel-for-landslide-and-debris-flow-prediction-using-multiple-hydrometeorologicalvariables

\section{Hosted file}

Figugre_10.docx available at https://authorea.com/users/336123/articles/461900-an-evaluationmodel-for-landslide-and-debris-flow-prediction-using-multiple-hydrometeorologicalvariables

\section{Hosted file}

Figugre_11.docx available at https://authorea.com/users/336123/articles/461900-an-evaluationmodel-for-landslide-and-debris-flow-prediction-using-multiple-hydrometeorologicalvariables

\section{Hosted file}

Table_1.docx available at https://authorea.com/users/336123/articles/461900-an-evaluationmodel-for-landslide-and-debris-flow-prediction-using-multiple-hydrometeorologicalvariables

\section{Hosted file}


Table_2.docx available at https://authorea.com/users/336123/articles/461900-an-evaluationmodel-for-landslide-and-debris-flow-prediction-using-multiple-hydrometeorologicalvariables 